\title{
U.S. Land Policy, Property Rights, and The Dust Bowl of the 1930s
}

\author{
Gary D. Libecap \\ University of Arizona \\ National Bureau of Economic Research \\ and \\ Żeynep K. Hansen \\ University of Arizona
}

DRAFT

April 23, 2001

Prepared for the Fourth Toulouse Conference on Environment and Resource Economics-Property Rights, Institutions, and Management of Environmental and Natural Resources, Toulouse, France May 3-4, 2001. Lee Alston and Ron Johnson provided comments on this draft. 
"In the morning the dust hung like fog, and the sun was as red as ripe new blood. A 11 day the dust sifted down from the sky, and the next day it sifted down.

An even blanket covered the earth. It settled on the corn, piled up on the tops of the fence posts, piled up on the wires; it settled on roofs, blanketed the weeds and trees." John Steinbeck, The Grapes of Wrath $(1939,6)$

\section{Introduction.}

The process of assigning property rights to land in the American Great Plains resulted in farms that were too small to be economically viable. Under the Homestead Act, hundreds of thousands of 160 to 320 -acre farms were founded between 1880 and 1920 . These farms were more likely to fail during drought, and because of the cultivation practices used on them, we hypothesize that small farms were principal contributors to the region's most significant environmental crisis, the Dust Bowl of the 1930s. Drought conditions returned to the Great Plains in the late 1950s and 1970s, yet there was no return to the Dust Bow1. New farming techniques and larger farms likely were major reasons.'

The path dependence resulting from the initial assignment of property rights on the Great Plains was slow to be corrected. The transactions costs of property rights reallocation from homesteads to larger farms were high, in part due to government intervention. Local politicians sought to retain the dense, Midwest-like population that homestead settlement had fostered, and they successfully lobbied the Federal Government for subsidies to maintain small family farms. An abrupt loss of rural population was not politically acceptable. The result was a halting process of farm size adjustment between 1920 and 1982. This case illustrates the difficult environmental problems that can be raised by an inappropriate assignment of property rights. It cannot be assumed that a more efficient allocation of rights with fewer negative environmental effects will occur quickly. As Ronald Coase noted, high transactions costs can impede the 
reallocation process, and as the Dust Bowl indicates, the environmental consequences can be very significant. Many environmental issues examined by economists and political scientists, such as common-pool problems, result from the absence of well-defined property rights. The issue examined in this paper, is a different, although related one. Here we address the environmental costs of an inappropriate allocation of property rights, where the rights distribution does not rapidly adjust to a more efficient arrangement.

\section{The Assignment and Reallocation of Property Rights.}

One of the most important lessons of Coase's 1960 article, "The Problem of Social Cost," was that the initial assignment of property rights did not matter for efficiency so long as the transactions costs of reallocation were zero. Various examples, such as the problem of damages inflicted by a cattle-raiser on a farmer's fields, were used to make the point that if property rights could be costlessly traded, then assignment of liability would have no long-run effect on the allocation and use of resources. Coase recognized, however, that if transactions costs were high, then the liability rule or property rights assignment did matter for the overall value of production: "In these conditions the initial delimitation of legal rights does have an effect on the efficiency with which the economic system operates. One arrangement of property rights may bring about a greater value of production than any other." Coase emphasized the transactions costs associated with searching and negotiating exchanges of rights. He did not stress the effects of political intervention that could impede transfers.

Recognizing that transactions costs generally are positive, three issues arise in the assignment of property rights and the internalization of externalities: What process determines the initial rights allocation; what are the social costs associated with the observed assignment; and what transactions costs might limit reallocation toward a more efficient arrangement? 
In this paper, we address all three issues by examining American land policy in the late $19^{\text {th }}$ and early $20^{\text {th }}$ centuries as it applied to the Great Plains. We argue that there were powerful political pressures for piecemeal division to meet broad demand for land. Small homesteads of 160 acres were efficiently sized for farming in the central and eastern parts of North America where rainfall was abundant. But they were not viable for more arid regions. Until the 1920s, however, there was little knowledge of the climate of the Great Plains or of appropriate farm sizes and farming practices for such a region. We examine the political economy of federal land policy to determine why it was not significantly adapted for the more arid conditions.

Second, we examine the social costs of the assignment of property rights to small farmers. By the 1920s, officials of the Agricultural Experiment Stations and Department of Agriculture recognized that small farms were more likely to fail during the droughts that periodically swept the region. We analyze the characteristics of farms that survived the severe 1917-21 drought in the northern Great Plains, using manuscript census data and county directories. Controlling for other factors, small farms were less apt to endure drought. Further, we argue that their cultivation practices during drought contributed to severe wind erosion. Because they were constrained by size, small farmers intensively cultivated their land, did not place portions in fallow, and did not diversify into pasture. Such cultivation made the soil more vulnerable to wind erosion, culminating in the Dust Bowl of the 1930s. The Dust Bowl was one of the most serious environmental events of the $20^{\text {th }}$ century, and we assert that the property rights assignment contributed directly to its severity. If verified, this is a point not made previously in the literature.

The third issue addressed in the paper is the nature of the transactions costs involved in consolidating farms, adjusting the original allocation of property rights toward farm sizes that 
better reflected the requirements of the region. Although small farms were more likely to fail during any particular drought, the process of consolidation took a long time. To demonstrate the process of property rights adjustment we compare changes in farm size between 1920 and 1987 in the Great Plains region and in the Midwest where small farms were viable. We also include data for a major wheat-growing region of Australia, New South Wales, where the climate was similar to that in the Great Plains. Changes in the relative prices of labor and capital led to larger farms in all regions. We argue, however, that because farms in the Great Plains started off"too small," more drastic farm size changes were required than took place in the Midwest or in Australia. Yet, local politicians and community leaders resisted the loss of rural population associated with farm consolidation and lobbied for subsidies to maintain the farm population. Small family farmers were an important political constituency. ${ }^{3}$ Beginning in the 1930 s, the Federal Government provided substantial relief payments to small farms. Although these supplemented farm-based income, they prolonged the operation of inefficient, small farms and delayed the transition to larger units. Additionally, homesteaders were risk takers and they resisted selling their properties for consolidation.

\section{U.S. Policy for the Assignment of Property Rights to Land.}

From the beginning, U.S. land policy emphasized small-farm distribution. Thomas Jefferson claimed that: "The small landholders are the most precious part of the state." ${ }^{4}$ The Homestead Acts were the most important policy vehicle. Under the 1862 law, any family head could claim between 40 and 160 acres, and upon 5-years continuous residence and improvement (cultivation), receive title. This allocation arrangement worked well in northern agriculture east of the $100^{\text {th }}$ meridian, where there were no important economies of scale and where there was sufficient rainfall (above 30 inches a year). As migrants moved across the frontier, they could 
transplant farming practices, crops, and farm sizes used to the east or in Europe. Under these circumstances, property rights were assigned quickly and agriculture developed rapidly, with livestock and grain production a major contributor to GNP. No important externalities were left uninternalized.

By 1880, however, the frontier reached the Great Plains (Figure 1), and conditions were quite different. In his Report on the Arid Lands of North America made to Congress in 1878, John Wesley Powell warned that past methods of agricultural settlement could no longer be relied on and called for 2,560-acre homesteads. The proposals were not adopted. ${ }^{5}$ There was debate in Congress as to whether the remaining portions of federal lands were sufficiently arid to require a revision of the land laws. There was no body of scientific knowledge that supported Powell's claim. Western representatives sought to have as much land made available to as many claimants as possible. Powell's suggested allocations were 16 times the size of existing allocations, and the proposals were considered extreme. They would have broken from the past small-homestead policy and drastically reduced the number of farmers that could settle in the region. ${ }^{6}$ This would have reduced its population and political influence, relative to the Midwest and East. Members of Congress from western states and territories were virtually unanimous in their opposition.' Once homesteads were established, small family farmers became an influential constituency that politicians sought to protect.

During major migration to the Great Plains between 1880 and 1920, there were no longterm weather records to document the limited and fluctuating precipitation of the region. Neither the agricultural experiment stations nor the US D A had experience with dry land farming to recommend appropriate agricultural techniques for semi-arid conditions. ${ }^{8}$ During wet periods, the Great Plains were extremely productive with high crop yields, and small-farm, eastern 
agriculture could be quite successful. During drought, however, yields would collapse, and small farms would be at risk.

Absent much understanding of the weather, various doctrines were accepted as ameliorating the problem of potential aridity. One was "rain follows the plow," a notion that rainfall was endogenous with settlement, and through cultivation, precipitation would increase. The other was dryfarming doctrine that asserted that through intensive cultivation of small farms sufficient moisture could be stored in the soil to counter any drought period. Severe droughts in the southern plains in 1893-94 tended to discredit the notion that rainfall was increasing, but dryfarming doctrine remained dominant until the early 1920 s.

Under these conditions, hundreds of thousands of migrants moved to the Great Plains to establish small farms. Between 1880 and 1925, 1,078,123 original homestead entries were filed to $202,298,425$ acres in western Kansas, Nebraska, and the Dakotas and eastern Colorado and Montana, 45 percent of all homestead filings and 48 percent of all government land claimed during the period. ${ }^{9}$ This homestead entry led to the proliferation of small farms in the region.

Table 1 documents the pattern of settlement with mean farm size and percent of farms below 500 acres from 1880 through 1987 for the Great Plains and Midwest. Notice that in the Midwest homesteading was stable and small farms were viable. There was little change in mean farm size between 1880 and 1950, and small farms below 500 acres accounted for over 90 percent of all farms through 1964. In the Great Plains, homesteading led to an influx of new 160 to 320 -acre farms through 1920 , with farms under 500 acres accounting for over 70 percent of all farms. The number of farms grew by more than four fold between 1880 and 1920. Beyond 1920, however, mean farm size grew and the portion of farms below 500 acres declined.

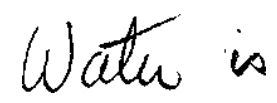


With so little climate information about the Great Plains and no past experience with arid land agriculture, there was no imperative for changes in property rights policy. Other than Powell, there were no advocates for major changes in land laws. A number of small adjustments were made, chief of which was the 1909 Enlarged Homestead Act which granted title to 320 acres of land after 5-year's residence and continuous cultivation. This beneficial use requirement subsequently would contribute to wind erosion during drought. The law applied to Colorado, Montana, Nevada, Oregon, Utah, Washington, Wyoming, Arizona, and New Mexico. Generally, the other Great Plains states of North and South Dakota, Kansas, and Nebraska were settled under the original 160 -acre homestead law. ${ }^{10}$

Analysis of the vote on the Enlarged Homestead Act illustrates the political forces underlying land policy. " As in past congressional debates over revising land laws, larger allocations, in this case 640 acres, were rejected as leading to "land monopoly." ${ }^{12}$ There were no strong proponents of larger distributions. 320 acres, twice the size of existing homesteads, seemed sufficient for the Great Plains. The proposed change passed 141 to 74 in the House of

Representatives, with 172 abstentions on May 11, 1909, and subsequently, became law.

In the Probit analysis, we examine the yes votes, and since there were so many abstentions, we also examine abstentions. Representatives of frontier states were not convinced that large homesteads were required, and they favored only moderate adjustments in the land laws. Their objective was to promote dense settlement of the Great Plains. Frontier states are indicated by percent change in state population between 1900 and 1910 that was largest on the frontier. Congressional debates do not indicate serious opposition to the proposed doubling of homestead plot size to 320 acres. In other land law debates, representatives of midwestern states had voiced skepticism about the need to open yet more land and greater agricultural production 
that would depress commodity prices. ${ }^{14}$ It is possible that similar concerns existed in 1909 . To test for that possibility, the value of corn production by state in 1910 was included. Midwestern states were primarily com producers, and these were the states where new production might have been of greatest concern. Migration to the frontier also may have attracted labor from manufacturing states and thereby placed some pressure on wages. To test whether representatives of manufacturing states opposed making the frontier more attractive to migrants, we included value of manufacturing by state in 1910. We also added dummy variables for party (Republican). ${ }^{15}$

The estimated equations are:

Yes $/$ Abstentions $=\mathrm{b}+\mathrm{a} 1$ population change $+\mathrm{a} 2$ value of com production $+a 3$ value of manufacturing + a4 Republican. ${ }^{16}$

The results are reported in Table 2. Although representatives of frontier states earlier opposed much large allocations of federal land, they were in favor of this limited expansion of homestead plots. The coefficient on the frontier variable, population change, is positive and significant. Representatives of frontier states also generally were less likely to abstain from voting. Representatives from midwestem states also favored the legislation and did not abstain. Representatives of states that had high values of manufacturing in 1910, largely from the Northeast, however, opposed the legislation or abstained from voting for it.

The results show generally broad western and midwestem support for the slightly liberalized 1909 homestead law. It became the basis for most settlement of the upper Great Plains. In some areas, dense homestead settlement led to a decline in average farm size as settlers claimed and subdivided available federal land. For example, in Fergus County, Montana in 1904 prior to major homestead migration there were 472 farm units with average size of 1,300 acres. 
By 1916 the number of units had grown by nearly ten fold to 4,018, and farm size had fallen to 391 acres, a decline of 70 percent. ${ }^{17}$

\section{Small Homestead Farms and Drought.}

The distinguishing characteristic of the Great Plains is its aridity and fluctuating rainfall. Severe drought, defined as rainfall on standard deviation below the mean, has no predictable trend. The problem of small farms and drought is repeated throughout the historical and agricultural economics literature after 1920. USDA and Extension Service personnel blamed US land policy for placing hundreds of thousands of small farms on site, and policies to encourage larger farms were urged. ${ }^{19}$ For example, the U S D A Yearbook of Agriculture (1940, 409) concluded: "The ill-advised application of homestead policies to this territory [Great Plains] divided the land into small units of 320 or 640 acres, where operating units of several sections [1,280-1,920 acres] were requisite."

There were numerous problems with small homesteads. One was that because of their limited size, it was impractical to diversify from wheat into livestock. Cattle were attractive because they could be raised even when wheat yields were low, and real wheat and cattle prices were not correlated (.09). Maintaining some livestock could be a means of smoothing incomes. ${ }^{2}$ Further, because of grass cover pastureland was much less vulnerable to wind erosion during drought. In contrast, because they were intensely cultivated, small farms increased the risk of wind erosion.

Under wet conditions and high wheat yields, a small enterprise could produce enough to sustain a family by placing the entire farm in crops. Returns were comparable to mean farm earnings elsewhere in the country. Continuous cropping, however, resulted in the land being plowed and cultivated throughout the year without the use of fallow. Fallow was a practice of 
idling half of a farm each year with protective mulch to collect moisture and nutrients. But only larger farms could afford to keep so much land out of production. Strip cropping (alternating bands of fallow and crop) and other practices designed to mitigate drought and protect soil against wind were not feasible. As a result, drought was much more devastating to homesteads than to other farms. Loan foreclosures and farm abandonment were much higher for homesteads than for larger farms in the Great Plains.

County Directories show the effect of drought on small homesteads. Directories for Cascade and Fergus County, Montana in the early part of the twentieth century provide lists of farms by size. In 1916, at the peak of homesteading, there were 3,960 farms in Fergus County and 2,193 in Cascade County. A severe drought, however, hit the northern plains between 1917 and 1921, and many farms failed. As shown in Table 3, larger farms were more apt to survive. In Fergus County 28 percent of the farms survived to 1922, and these farms were about 33 percent larger in 1916 than were those that failed. ${ }^{23}$ Similarly in Cascade County, 33 percent of the farms survived to 1923, and they were about 22 percent larger than non-survivors. Farms that were larger in 1916 also were more likely to endure through the decade.

Additionally, one of the few surviving agricultural census manuscript records for 1920 includes Carbon County, Montana, an area partially in the Great Plains. We also have County Directory data that list farmers and farm sizes. Comparing the 1916 and 1919 and 1922 Carbon County Directories allow us to identify which farmers were in residence in 1916 and 1919 to be matched with the census data and to determine who survived the drought through $1922 .{ }^{24}$

Using the 1916 and 1919 county directories, we identified 726 farmers who were in Carbon County in both years. Many were homesteaders. ${ }^{25}$ The 1922 directory shows that 299 survived the drought, giving an overall survival rate of 42 percent. Using the names from the 
1916 and 1919 directories and matching them with those in the 1919 census manuscript provides a sample of 138 farmers. Of those 138 farmers, 68 survived to 1922, for a survival rate of 49 percent, slightly better than the total sample, and 70 were non-survivors. ${ }^{26}$

With these data we can isolate the characteristics of successful farms. ${ }^{27}$ For the statistical analysis of survivors and non-survivors, we removed farmers who had holdings of less than 80 acres, untypical of dryfarming regions, and who were 65 years or older. ${ }^{28}$ This left a sample of 109 farmers, with 61 surviving through 1922. The census data include age, employment history, farm size, crop and pasture land, asset value, crops and livestock, and products sold.

Survival $=$ Allocation dummies, farmer age, total crop acres, total pasture acres, farm value per acre, value of livestock, value of wheat sales).

\section{0}

Farmer age is a proxy for experience. Total crop acres are derived from the census data for crop acres harvested, crop acres failed, and crop acres fallow or idle. This is the key farm size variable. In Carbon County, farms were divided into crops and pasture, with the best lands for crops and the least productive for pasture..$^{30}$ The county was not an important livestockproducing area. Hence, total crop acres reflect the size and potential productiveness of the farm. Total pasture indicates less productive land, with a negative effect on survival. Farm value/acre is farm value as listed in the census /total farm size. ${ }^{31}$ The variable declines with farm size and should be negatively related to survival. Livestock value included the value of cattle, dairy cattle, sheep, hogs, and poultry, and is included as a proxy for livestock sales to test for the effects of diversification from wheat. ${ }^{32}$ The value of wheat sold is total wheat bushels sold times wheat prices received by farmers in 1919 per bushel. ${ }^{33}$ This income variable examines the effect of the size of wheat earnings on survival. ${ }^{34}$ 
The results of the probit analysis are shown in Table 4. As shown in the table, farmer age is an important factor in farm survival. The major farm size variable, total crop acres contributed to survival, while pasture acreage did not. Both the values of wheat sales and livestock have a positive effect, but only livestock is significant at the 10 percent level. The other financial variable, farm value per acre, has a negative coefficient and is significant at 5 percent level. Farm value per acre decreased with size and larger farms tended to survive.

Mean farm size for the 61 surviving farms was 157 crop acres and 375 total acres, whereas for the 48 non-surviving farms, it was 129 crop acres and 331 total acres. Survivors then were about 18 percent larger in terms of crop acres and 12 percent larger for total acres than those farms that failed. Surviving farms were not only larger, but they were more diversified into livestock. The mean value of livestock for survivors was $\$ 1,906$, more than double the mean of $\$ 817$ for non-survivors. Wheat sales also were higher for survivors at $\$ 277$ on average, compared to $\$ 189$ for non-survivors.

A farm with the mean sample characteristics had a 61 percent chance of survival. Increasing total crop acres by one standard deviation raises probability of survival to 72 percent, and if the value of wheat sales also is increased by one standard deviation, the probability of survival rises to 80 percent. These results underscore the general observation that larger farms were more likely to survive the drought.

The agricultural economics literature in the 1930s stressed size as the key factor in enduring drought. For example, Renne $(1936 b, 4)$ criticized the Homestead Acts for leading to the proliferation of small uneconomical holdings in the northern plains. In commenting on drought and farm failure on the Great Plains, Johnson $(1937,153,162)$ cited the problem of homesteads. Starch $(1939,119)$ argued that farms had to be diversified into wheat and livestock 
to withstand dry periods, but noted that sufficient livestock were not possible on small units. Clawson, Saunderson and Johnson $(1940,34)$ pointed to widespread loan foreclosures and the subsequent abandonment of small farms. Huffman and Paschal $(1942,17)$ claimed that even in 1942: "Many operators still are trying to farm land unsuited to cultivation. Their units are too small and they have little security against drought."

\section{Small Farms and the Dust Bowl.}

The Dust Bowl was certainly one of the major environmental crises of the twentieth century in North America. ${ }^{35}$ Intense wind erosion began in the northern plains in 1931 and moved to the south and lasted through 1940. 1938 was the peak year. The storms were huge, some 600 by 400 miles, lasting 10 hours or more. One dust storm in May 1934 started in Montana and spread south, carrying some 350 million tons of soil toward the East Coast. During a storm of February 7, 1937, 34.2 tons of soil fell per square mile at Ames, Iowa, 14.9 tons at Marquette Michigan, and 10 tons across the continent in New Hampshire. ${ }^{36}$ Johnson $(1947,194-$ 5) estimated that in 1935 alone 850 million tons of topsoil had blown away from 4,340,000 acres in the southern plains.

By 1935, 65 percent of the total area of the Great Plains had been damaged by wind erosion, with 15 percent severely affected. Erosion was greatest in Oklahoma, impacting over 70 percent of the land, with 18 percent of Texas, 25 percent of Colorado, 16 percent of $\mathrm{New}$ Mexico, 30 percent of Kansas, and 17 percent of North Dakota damaged. ${ }^{37}$ By 1938, the Soil Conservation Service estimated that 80 percent of the land in the southern plains had been subject to wind erosion, with 40 percent to a serious degree. 10,000,000 acres had lost the upper five inches of topsoil, and 13,500,000 acres had lost 2 1/2 inches, with an average loss of 480 tons of topsoil per acre. Dust smothered adjacent range and crop land. ${ }^{38}$ 
Because light, rich topsoil was most likely to be carried away, leaving sandy infertile soil behind, wind erosion depleted soil quality and productivity. Damaged areas required the addition of fertilizers and organic material to reconstruct soil productivity. Samples of soil carried 500 miles from Texas to Iowa had 10 times as much organic matter, 9 times as much nitrogen, 19 times as much phosphoric acid, and 45 percent more potash as compared to the soil that remained..$^{39}$

The Great Plains is a transitional climatic region most often affected by drought and has the continent's strongest winds. Under normal conditions of ground cover, wind erosion is a normal geologic process, but with sufficient cover the soil historically has not been seriously affected. ${ }^{40}$

Following Gutmann and Cunfer (1999, 9-10) wind erosion occurs as strong winds blow across dry soil. Beyond a threshold speed that varies according to soil characteristics and moisture, soil particles begin to move. The amount of erosion from a field is a function of the textural class of the soil (sandy soils are most vulnerable), slope, wind velocity, soil moisture, vegetative cover, surface aggregates (dumpiness lowers surface wind velocity), and size of exposed terrain.

With homestead settlement of the Great Plains the conditions for increased wind erosion were established. The native grasses were plowed as the land was placed into crops, and intensive cultivation reduced the size of soil particles. The soil, especially in the southern plains, already was sandy, and the region was flat with little to obstruct wind. In the 1930s, severe drought and high temperatures also lowered soil moisture. The soil became dust and was picked up by the wind.

Drought in the 1930s was a triggering factor for the Dust Bowl, but it was not a sufficient 
condition. Figure 2 plots annual rainfall in three Great Plains states of Kansas, Montana, and Colorado from 1895 to 1985 . Notice that severe drought (precipitation one standard deviation below the mean) characterized the 1930s in all three states. Those were the Dust Bowl years. Notice too that the late 1950 s and late 1970s were also periods of severe drought. Nevertheless, neither of the latter two periods had wind erosion comparable to that experienced in the 1930s.

We emphasize two major and related differences between the 1930s and the 1950s and 70 s. One was that by the 1950 s, there was greater knowledge of cultivation techniques and land use practices that could mitigate wind erosion. Second, there were fewer small, homestead farms. As indicated in Table 1 average farm size in the Great Plains in the 1930s was approximately 640 acres, whereas in the late 1950s, mean farm size was twice that at approximately 1,300 acres, and by the late 1970 s, larger still at over 1,600 acres. The keyinitiating factor for the 1930's Dust Bowl was cultivation, and small farms cultivated more of their land, and cultivated it more intensely than did large farms. ${ }^{41}$

Homestead farms also were too small to adopt the conservation practices that were found to be important for controlling wind erosion. USDA and Soil Conservation Service officials in the 1930s and subsequent investigators repeatedly cited small farms on the Great Plains as a principle source of the region's problems. They lamented the failure to adopt Powell's recommended 2,560-acre plots. ${ }^{42}$ For example, Bennett and Fowler $(1936,6-7)$ stated that federal homestead policy to keep land allotments small and to require that a portion be plowed "is now seen to have caused immeasurable harm." The Great Plains Committee (1936, 3, 40-6, 75), appointed by President Roosevelt to address poverty and environmental damage concluded that "although we now know that in most parts of the Great Plains a farm of this size 
[homestead] is far too small to support a family. They were required to put this land under plow, regardless of whether or not it was suited to cultivation."

Small marginal homesteads had to be completely cultivated to earn sufficient income to support a family. They were continuously cropped and cultivated, raised few livestock and therefore had little pasture and the associated protective grass cover. With declining agricultural prices in 1933 and dry conditions, small farmers especially had to plant as much as possible on their plots to try to offset falling yields and returns. Cooper, et al, $(1938,146-8)$ claimed that farms "are so small that the establishment of a system of farming that will conserve soil and produce a desirable family income is practically impossible."

As the Dust Bowl continued through the 1930s, soil conservation recommendations included a variety of cultivation techniques — strip cropping, wide spacing of crops with double width rows and partial fallow, contour plowing, stubble mulching and specialized plowing that maintained stubble cover, and reduced tillage. A11 of these practices required leaving about half of a farm uncultivated each year and the use of specialized equipment (duck foot plows, bar blade and rod weeders, shearing blades, improved tractors and combines) as well as new drought-resistant grains. ${ }^{43} \mathrm{With}$ limited acreage and high fixed investments, small farms were less apt to use these techniques or have the appropriate equipment.

Diversification into livestock also was recommended because maintaining pasture retained grass cover, but given low grazing capacities livestock made sense only for large units (Starch, 1939, 119). Similarly, Thornthwaite $(1936,242)$ concluded that the small size of many farms precluded cattle raising and forced the cultivation of land which should have remained in grass, "... in addition, the type of tillage which, because of its low cost, gives the farmer his 
only advantage is the primary cause of wind erosion so destructive in nature that it eventually renders the land unfit for cultivation."

\section{Transactions Costs and the Effect of Government Subsidies to Small Farms in the Slow Transition to Larger Farms.}

The assignment of property rights to homesteads in the Great Plains created a small-farm path dependency that was slow to be corrected. Figure 3 presents mean farm size from 1920 through 1987, constructed from census data for the Great Plains and the Midwest and for New South Wales, Australia. New South Wales accounts for approximately one-third of Australian wheat production and has a climate similar to that found in the Great Plains. The Great Plains states include eastern Montana, eastern Colorado, the western Dakotas, western Kansas, and western Nebraska. The Midwestern states include Wisconsin, Minnesota, Iowa, eastern North and South Dakota, eastern Nebraska, and eastern Kansas. ${ }^{44}$ The figure also shows the linear regression of farm size on time. A fourth line projects the change in farm size retrospectively using the estimated size adjustment found in the Midwest.

As illustrated, in the Midwest, farm sizes only gradually changed. Between 1920 and 1987 mean farm size approximately doubled from 175 acres to 371 acres, with the slope of the estimated adjustment equal to 3.3. The experience of the Great Plains was quite different. Mean farm size in 1920 was 557 acres, and it tripled to 1,648 acres by 1987, with the slope of the estimated adjustment equal to 19.9. For New South Wales, farm size is 2,010 acres in 1920 and rises to 2,862 acres by 1978 , the last year for which we have data. The slope of the adjustment is 5.9, which would be lower except for the spike in farm sizes in 1978. Even so, the adjustment path is similar to that found in the Midwest.

Kislev and Peterson (1982) analyzed the growth in farm size for the United States as a 
whole from 1930-1970, where per farm size grew at an annual rate of 2.2 percent. They attribute this growth to changes in the relative price of farm labor to machinery, which grew at almost the same rate. Further, they argued that technical improvements were similar across machine types. The 160-acre limit of the Homestead Act was not a binding constraint in the Midwest. As late as 1920, a 160-acre farm was close to optimal in the region. From that time forward, only relatively moderate farm-size adjustments took place in response to changes in the relative factor prices. The homestead limit was binding on the Great Plains. Because of the dryer climate and variable precipitation that led to fluctuating yields, farms needed to be larger than the 160 or 320 acres allowed under the land laws. Through gradual consolidation of units, farm size increased over time, with the adjustment process slowing after 1960. As indicated in Figure 3, the change in farm size moderated after 1965, suggesting that by that time much of the "catchup" from small homesteads had taken place.

Assuming that the following arrangement for both regions:

$\Delta f_{t}=\mathrm{g}\left(f_{0}-f_{t}, \rho\right)$, where $f_{0}$ is optimal farm size in year $\mathbf{t}, f_{t}$ is actual farm size, $\rho$ is relative factor prices, and $\left(f_{0}-f_{t}\right)=\mathrm{h}$ (land laws, climate). Accordingly, in the Midwest and New South Wales annual farm size change is in response to factor prices, as suggested by Kislev and Peterson, since $\left(f_{0}-f_{t}\right)$ drops out. The land laws did not distort farm size relative to the region's climate. In the Great Plains, however, farm size changes must be greater to move from the homestead constraint and react to factor prices.

A comparison between changes in farm sizes in the two regions over the 67 -year period illustrates the property rights adjustment problems caused by starting with farms that were too small on the Great Plains. If farm units on the Great Plains had not been constrained by the 
provisions of the land laws and if the factors influencing farm size adjustments had been the same in both regions, except for climate, it is possible to determine what the optimal farm size might have been in 1920. Starting with the 1987 mean farm size in the Great Plains and moving back across time using the Midwest farm size adjustment as a baseline, results in a 1920 wheat farm size of 1,441 acres. Such a farm was 9 times larger than a 160 -acre homestead and 4.5 times larger than a 320-acre homestead, as allowed by law, although still smaller than that found in New South Wales.

Table 5 also describes the nature of the farm-size adjustment process on the Great Plains. It provides census data for two Great Plains states, Colorado and Montana for 1920 and 1982, the two end points of our analysis. In 1920, mean farm size in the two states was 408 and 608 acres, respectively. Most of the farms were less than 500 acres, and there was considerable heterogeneity in farm sizes as indicated by the coefficient of variation, which was 2.7 for Colorado and 2.3 for Montana. By 1982, however, mean farm size was much larger at 1,237 and 2,568 acres. Further, the variance in farm size had declined. The coefficient of variation was 1.67 for Colorado and .92 for Montana. Farm sizes had coalesced around the mean.

Following the drought of 1917-21, it became increasingly clear that homesteads were not viable farm units on the Great Plains, yet they persisted and were only gradually replaced by larger units, as reflected in Figure $3 .^{45}$ There are a number of reasons for the slow reallocation of property rights. One is that there was no abrupt end to homestead farms through severe drought. Precipitation varied by region and year, so that if homesteaders survived one drought, they stayed as conditions improved. ${ }^{46}$ Farmers only had to cover the opportunity costs for variable inputs, labor and capital, and their human capital was linked to agriculture with few other options in the region other than migration. Hence, farmers were reluctant to sell, staying on their farms 
as long as possible. Further, during wet conditions, homesteads performed well relative to other farms. Rainfall was uncertain, and since homesteaders were risk takers, they discounted future dry years and often rejected offers to sell their land. Another important reason is that small farmers were subsidized to continue.

Although in the early 1930 s the Federal Government attempted to encourage outmigration and the formation of larger farms on the Great Plains through the Resettlement Administration, it had limited success..$^{47}$ In most cases the government purchase and resettlement programs eventually were resisted. ${ }^{48}$ Only 581,696 acres were purchased in the southern plains. Opponents alleged that the government was purchasing farms during a period of distress and taking them out of production. Government lands were removed from the local tax base.

The real thrust of government policy through relief and Agricultural Adjustment Act payments was to sustain family farms. The Department of Agriculture did not want to see a dramatic loss of farmers in the region. In its 1938 Yearbook of Agriculture, "Soils and Men," the agency noted the debate over whether to move farmers out of farming or to subsidize them, and sided with the latter: "it is wise to keep a large rural population"(pages 3-4). The department did not want to see a loss of its constituency in the region. Clawson, Saunderson, and Johnson (1940, 42-8) claimed that eliminating farms of less than 300 acres in eastern Montana would reduce the number of farms by 76 percent. But they doubted that many would be willing to accept such drastic steps. They still called for the elimination of 50 percent of the farms in the region from 1928-35 levels, and predicted it would take 30 years to do so with considerable government assistance.

Thornthwaite $(1936,243-5)$ suggested that the Great Plains could sustain only two-thirds of the 1930 population. ${ }^{50}$ But politicians feared such a loss in farm population and the related 
deterioration in local economic activity and national political influence. The number of representatives in the House was at stake. They lobbied for subsidies to maintain small farms through the Farm Security Administration, the Works Progress Administration, the Farm Credit Administration, and the Federal Emergency Recovery Administration. For example, \$525 million was authorized in June 1934 for the region as drought relief. ${ }^{51}$ The major historian of the Dust Bowl, Donald Worster $(1979,131-5)$ estimated that 3 out 4 farmers in the region received federal aid. Johnson $(1947,190)$ noted that in some areas as many as 80 percent of the farmers were on relief. A March 1935 survey indicated that up to 40 percent of farm families in the Texas panhandle, over 50 percent in southeastern Colorado, and between 33 and 50 percent in southwest Kansas was dependent on government payments. Between September 1933 and August 1935, FE R A granted \$32,666,370 to Colorado, Kansas, and Oklahoma for relief. Those not on reliefwere able to stay on their farms mainly because of crop adjustment payments from the A A A. Between 1933 and 1936, total federal aid averaged \$223/person in 72 southern plains counties. ${ }^{52}$ The subsidies, however, helped to sustain many otherwise non-viable small farms, delaying the adjustment toward larger farm sizes. ${ }^{53}$ Wheat farms received approximately one third of their income from federal subsidies (Rucker and Alston, 1987).

Small farmers became an important political constituency. Although, larger units gradually replaced homesteads, the "family-farm" lobby became increasingly effective in securing preferential government support. In the 1930s and later in the 1970s, the lobby was able to secure legislation in Great Plains states to prohibit large 'corporate' farms. ${ }^{54}$

\section{Conclusion..}

The Homestead Acts resulted in the formation of farms that were inappropriately small for the semi-arid Great Plains. Cultivation practices on those farms had important environmental 
consequences during drought. Had there been more complete knowledge of the climate and agricultural techniques suitable for the region in the late nineteenth and early twentieth centuries, the land laws might have been more significantly broadened to allow for much larger property rights allocations. As it was, the area was settled densely with small, family farms along a midwestem model. The process of consolidation of 160 and 320-acre homesteads into more viable units took a very long time. In the mean time, homesteads were more vulnerable to failure during drought, and we argue they disproportionately contributed to the Dust bowl of the 1930s.

A lack of alternatives and government relief and agricultural subsidies beginning in the 1930s slowed the reallocation of property rights by providing income supplements to small farmers. Regional politicians sought to maintain family farms and to prevent a sharp decline in rural population. Gradually, larger farms replaced homesteads, but family farms remained a powerful political constituency.

This case illustrates the difficult environmental problems that can be raised by an inappropriate assignment of property rights. It cannot be assumed that a more efficient allocation of rights with fewer negative environmental effects will occur quickly. In this situation, government policies raised the transactions costs of the reallocation of property rights to more efficient units. A similar problem exists in water allocation in the western United States where transfers from agriculture and across regions are restricted. Yet, current water rights allocations lead to inefficient use and related environmental costs. 


\section{Bibliography}

Alston, Lee J., 1983, "Farm Foreclosures in the United States During the Interwar Period," Journal of Economic History. 43(4): 885-903.

Bennett, Hugh H. and Frederick H. Fowler, 1936, Report of the Great Plains Drought Area Committee. Washington D.C.: Government Printing Office.

Bennett, Hugh H., 1939, Soil Conservation. New York: McGraw-Hill.

Bennett, John, B., F.R. Kenney, and W.R. Chapline, 1938, " The Problem: Subhumid Areas," Soils and Men. Yearbook of Agriculture.1938. USDA, Washington D.C.: Government Printing Office, 68-110.

Benton, Alva H. 1925, "Large Land Holdings in North Dakota," Journal of Land and Public Utility Economics. 1: 405-13.

Blouet, Brian W. and Frederick C. Luebke, eds, 1979, The Great Plains: Environment and Culture. Lincoln: University of Nebraska Press.

Bonnifield, Paul, 1979, The Dust B ow 1 Men. Dirt, and Depression. Albuquerque: University of New Mexico Press.

Butcher, Walter R. and Norman K. Whittlesey, 1966, "Trends and Problems in Growth of Farm Size." Journal of Farm Economics. 48: 1513-1521.

Clawson, Marion, M.H. Saunderson, and Neil W. Johnson, 1940, "Farm Adjustments in Montana, Study of Area IV: Its Past, Present, and Future," Montana Agricultural Experiment Station Bulletin No. 377. Bozeman, January.

Clawson, Marion, 1958, "An Institutional Innovation to Facilitate Land Use Changes in the Great Plains," Land Economics. February, 74-9.

Coase, Ronald, 1960, "The Problem of Social Cost," Journal of Law and Economics. I11: 1-44.

Conkin, Paul, K., 1959, Tomorrow a New World: The New Deal Community Program. Ithaca: Cornell University Press.

Cooper, M.R., W.J. Roth, J.G. Maddox, R. Schickele, and H.A. Turner, 1938, " The Causes: Defects in Farming Systems and Farm Tenancy, Soil and Men. Yearbook of Agriculture.1938. US D A, Washington D.C.: Government Printing Office, 137-222.

Demsetz, Harold, 1967, "Toward a Theory of Property Rights," American Economic Review. 57 (2): $347-59$. 
Donaldson, Thomas, 1884, The Public Domain. Its History, with Statistics. Public Land Commission, Washington D.C.: Government Printing Office.

Cavert, William L., 1955, "he Technological Revolution in Agriculture, 1910-1955."Agricultural History. 29: 18-27.

Clements, Frederic E., 1938, "Climatic Cycles and Human Population in the Great Plains," Scientific Monthly. September, 193-210.

Eckert, Phil S. and Orlo H. Maughan, 1939, "Farm Mortgage Loan Experience in Central Montana," Montana Agricultural Experiment Station Bulletin No. 372. Bozeman, June.

Finley, Robert M., 1968, "A Budgeting Approach to the Question of Homestead Size on the Plains," Agricultural History. 42: 109-114.

Fite, Gilbert C, 1966, The Farmers' Frontier. 1865 to 1900. New York: Holt, Reinhart, and Winston.

Gray, L.C., 1939, "Federal Purchase and Administration of Submarginal Land in the Great Plains," Journal of Farm Economics. 21. 123-131.

Grimes, W.E. 1928, "Trends in the Agriculture of the Hard Winter Wheat Belt," Journal of Land and Public Utility Economics. 4: 347-54.

,1931, "Social and Economic Aspects of Large Scale Farming in the Wheat Belt." Journal of Farm Economics. 13. 21-6.

Gutmann, Myron P. and Geoff Cunfer, 1999, "A New Look at the Causes of the Dust Bow1," The Charles L. Wood Agricultural History Lecture Series 99(1): 1-25.

Halcrow, Harold G. and Roy E. Huffman, 1949, "Great Plains Agriculture and Brannan's Farm Program," Journal of Farm Economics. 31: 497-508.

Hargreaves, Mary W.M., 1976, "Land-Use Planning in Response to Drought: The Experience of the Thirties," Agricultural History. 50(4): 561-82.

Hauter, L.H., 1931, "A Five-Year Economic Study in the Dry Farming Area," Journal ofFarm Economics. 13, 632-35.

Heisig, Carl P., H.L. Boyle, and G.W. Forster, 1947, "Economic Implications of Technological Developments in Agricultural Production," Journal of Farm Economics 29: 299-309.

Hewes, Leslie, 1979, "Agricultural Risk in the Great Plains," in Brian W. Blouet and Frederick C. Luebke, eds, The Great Plains: Environment and Culture. Lincoln: University of Nebraska Press, 157-85. 
Hibbard, Benjamin H. 1924, reissue, 1965, History of Public Land Policies, New York: Macmillan.

Holmes, C.L., 1929, "Prospective Displacement of the Independent Family Farm by Large Farms or Estate Management and the Socioeconomic Consequences," Journal of Farm Economics. 11, 227-47.

Huffman, Roy E., 1942, "County Land as a Factor in Adjusting the Agriculture of Western North Dakota," The Journal of Land and Public Utility Economics. 18, 495-99.

Huffman, Roy E. and James L. Paschal, 1942, "Integrating the Use of Irrigated and Grazing Land in the Northern Great Plains," The Journal of Land and Public Utility Economics, $18,17-27$.

Hurt, R. Douglas, 1979, "Agricultural Technology in the Dust Bow1, 1932-40," in Brian W. Blouet and Frederick C. Luebke, eds, The Great Plains: Environment and Culture. Lincoln: University of Nebraska Press, 139-56.

, 1981, The Dust Bowl: An Agricultural and Social History. Chicago:

Nelson-Hall.

, 1985, "The National Grasslands: Origin and Development in the Dust Bowl." Agricultural History. 59: 246-59.

Johnson, E.C., 1939, "Discussion of Starch," Journal of Farm Economics. 21,120-122.

Johnson, Neil W., 1939, "Farm Adjustments in Montana," Montana Experiment Station Bulletin. No. 367, Bozeman, March.

Johnson, Sherman, E., 1932, "Readjustments in Organization in the Northern Great Plains in view of the Outlook for Agriculture," Journal of Farm Economics. 14, 442-46.

, 1933, "The Theory of Combination of Enterprises on Individual Farms," Journal of Farm Economics, 15, 656-669.

, 1937, "Land Use Readjustments in the Northern Great Plains," Journal of Land and Public Utility Economics. 8: 153-62.

Johnson, Vance, 1947, Heaven's Tableland: The Dust Bowl Story, New York: Farrar, Straus, and Co.

Keiser, Norman, 1956, " A n Analysis of the First Interim Report of the New House Committee on Family-Sizzed Farms," Journal of Farm Economics. 38: 988-1014. 
Kifer, R.S. and H.L. Stewart, 1938, Farming Hazards in the Drought Area. Works Progress Administration, Division of Social Research, Research Monograph X V I, Washington D.C.: Government Printing Office.

Kimmel, Roy I, 1940, " Unit Reorganization Program for the Southern Great Plains," Journal of Farm Economics. 22: 264-69.

Kislev, Yoav and Willis Peterson, 1982, "Prices, Technology, and Farm Size," Journal of Political Economy. 90 (3): 578-595.

Knoeber, Charles, 1997, "Explaining State Bans on Corporate Farming," Economic Inquiry. 35 (January): 151-66.

Kraenzel, Carl F., 1939, " Farm Population Mobility in Selected Montana Communities," Montana Agricultural Experiment Station Bulletin No. 371. Bozeman. April.

$571-88$.

, 1942, "New Frontiers of the Great Plains," Journal ofFarm Economics. 24:

, 1955. The Great Plains in Transition. Norman: University of Oklahoma

Press.

Kristjanson, Baldur H., and LeRoy W. Schafmer, "North Dakota Farm Size Trends: An Evaluation." Journal of Farm Economics. 31: 588-91.

Libecap, Gary D., 1981, Locking Up the Range: Federal Land Use Controls and Grazing. Cambridge: Ballinger.

Libecap, Gary D. and Zeynep K. Hansen, 2001,'"Rain Follows the Plow'and Dryfarming Doctrine: The Climate Information Problem and Homestead Failure in the Upper Great Plains, 1890-1925," working paper, Karl Eller Center, University of Arizona.

Miller, L.F. and W.B. Back, 1958, "Effect of Scientific Progress on Size and Efficiency of Farms in the Plains," Journal of Farm Economics40: 1250-62.

Nikolitch, Radoje, 1969, "Family-Operated Farms: Their Compatibility with Technological Advance," American Journal of Agricultural Economics. 51: 530-545.

Parsons, Kenneth H. and Wyn F. Owen, "Implications of Trends in Farm Size and Organization," Journal of Farm Economics. 33: 893-904.

Paschal, J.L. and P.L. Slagsvold, 1943, "Irrigation Development and Area Adjustment in the Great Plains," Journal of Farm Economics. 25: 433-43.

Perlman, Jacob, 1928, "The Recent Recession of Farm Population and Farm Land," Journal of Land and Public Utility Economics. 4: 45-58. 
Powe11, John Wesley, 1878, Report on the Lands of the Arid Region of the United States. 45 Congress, $2^{\text {nd }}$ Session, Executive Document, No. 73., Washington D.C.: Government Printing Office.

Peffer, E. Louise, 1951, The Closing of the Public Domain: Disposal and Reservation Policies. Stanford: Stanford University Press.

Renne, Roland, 1936a, "Western Land Policies and Recent Ownership Trends," Journal of Land and Public Utility Economics. 7: 33-43.

, 1936b, "Montana Land Ownership: An Analysis of the Ownership Pattern and Its Significance in Land Use Planning," Montana Experiment Station Bulleting No. 322. June, Bozeman.

, 1938, "Montana Farm Bankruptcies," Montana Agricultural Experiment Station Bulletin No. 360. Bozeman, June. , 1939, "Montana Farm Foreclosures," Montana Agricultural Experiment Station Bulletin No. 368. Bozeman, February.

Renne, Roland R. and O.H. Brownlee, 1940, "Uncollected Property Taxes in Montana," Montana Agricultural Experiment Station Bulletin No. 382. Bozeman, August.

Riney-Kehrberg, Pamela, 1992, "From the Horse's Mouth: Dust Bowl Farmers and their Solutions to the Problem of Aridity," Agricultural History. 66: 137-50.

Rucker, Randal R. and Lee J. Alston, 1987, "Farm Failures and Government Intervention: A Case Study of the 1930's," American Economic Review. 77 (4): 724-30.

Saunderson, M.H., R.B. Haight, E. M. Peterson, and Rex. E. Willard, 1937, "An Approach to Area Land Use Planning," Land Use Planning Publication. No. 16. U S D A, Resettlement Administration, Washington D.C.

Schickele, Rainer, 1949, "Farm Business Survival under Extreme Weather Risks," Journal of Farm Economics. 31: 931-43.

Schmidt, Louis Bernard, "The Agricultural Revolution in the Prairies and the Great Plains of the United States," Agricultural History. 8 (4): 169-95.

Shannon, Fred A. 1963, The Farmer's Last Frontier. Agriculture. 1860-1897. Volume V, The Economic History of the United States, New York: Holt, Rinehart and Winston.

Smith, Henry Nash, 1970, Virgin Land: The American West as Symbol and Myth. Cambridge: Harvard University Press, 1950, reissued. 
Starch, E.A., 1936, "Readjusting Montana's Agriculture, VII, Montana's Dry-Land Agriculture," Montana Experiment Station Bulletin No. 318. April, Bozeman.

,1939, "Type of Farming Modifications Needed in the Great Plains," Journal ofFarm Economics. 21, 114-120.

Steele, Harry, A. 1945, "Postwar Land Settlement Opportunities in the Northern Great Plains," Journal of Farm Economics27(2'): 405-18.

Steele, Harry A. and John Muehlbeier, 1950, "Land and Water Development Programs in the Northern Great Plains," Journal of Farm Economics. 32: 431-44.

Stegner, Wallace, 1954, Beyond the $100^{\text {th }}$ Meridian: John Wesley Powell and the Second Opening of the West. Boston: Houghton Mifflin.

Stephens, P.H., 1937, "Why the Dust Bow1?" Journal of Farm Economics. 19 (3), August, 75057.

Steinbeck, John, 1939, The Grapes of Wrath, New York: Viking.

Sturlaugson, Jonas, 1927, "The Size of Landholdings in Wisconsin," The Journal of Land \&Public Utility Economics. I11 (1), February, 308-22.

Thomthwaite, C. Warren, 1936, "The Great Plains," in Goodrich, Carter, et. al, eds, Migration and Economic Opportunity: Report of the Study of Population Distribution.

Philadelphia: University of Pennsylvania Press, 202-50.

United States Great Plains Committee, 1936, The Future of the Great Plains. Washington D.C.: Government Printing Office.

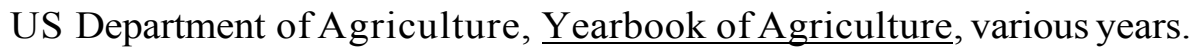

Vermeer, James, 1951, "Trends in Farm Size and Organization in the United States," Journal of Farm Economics. 33: 881-92.

Webb, Walter Prescott, 1931, The Great Plains. Boston: Ginn and Company.

Willson, E.A., H.C. Hoffsommer, Alva H. Benton, 1928, "Rural Changes in Western North Dakota," North Dakota Agricultural Experiment Station Bulletin No. 214, Fargo, January.

Worster, Donald, 1979, Dust Bowl: The Southern Plains in the 1930s. New York: Oxford University Press. 
Wright, K.T. "Should A11 Farms Be Large," Journal ofFarm Economics, 31: 592-95. 
Table 1

Average Farm Size in the Midwest and Great Plains

1880-1982

\begin{tabular}{|c|c|c|c|c|c|c|c|}
\hline \multicolumn{8}{|c|}{ Midwestern States } \\
\hline Year & $\begin{array}{c}\text { Mean } \\
\text { Farm Size }\end{array}$ & $\begin{array}{c}\text { Percent of } \\
\text { Farms }<500 \\
\text { acres }\end{array}$ & $\begin{array}{l}\text { Number of } \\
\text { Farms }\end{array}$ & Year & $\begin{array}{c}\text { Mean } \\
\text { Farm Size }\end{array}$ & $\begin{array}{c}\text { Percent of } \\
\text { Farms }<\mathbf{5 0 0} \\
\text { acres }\end{array}$ & $\begin{array}{l}\text { Number of } \\
\text { Farms }\end{array}$ \\
\hline 1880 & 174 & 99 & 845,520 & 1950 & 203 & 95 & $1,002,568$ \\
\hline 1890 & 152 & 98 & 971,215 & 1954 & 218 & 94 & 924,557 \\
\hline 1900 & 164 & 97 & $1,119,083$ & 1959 & 243 & 92 & 815,340 \\
\hline 1910 & 174 & 97 & $1,088,176$ & 1964 & 273 & 89 & 721,853 \\
\hline 1920 & 175 & 97 & $1,113,454$ & 1969 & 299 & 87 & 640,726 \\
\hline 1925 & 170 & 97 & $1,119,424$ & 1974 & 324 & 85 & 579,707 \\
\hline 1930 & 179 & 97 & $1,099,309$ & 1978 & 339 & 82 & 553,780 \\
\hline 1935 & 172 & 97 & $1,173,768$ & 1982 & 347 & 81 & 526,421 \\
\hline 1940 & 183 & 96 & $1,097,485$ & 1987 & 371 & 77 & 481,760 \\
\hline 1945 & 195 & 95 & $1,049,568$ & & & & \\
\hline \multicolumn{8}{|c|}{ Great Plains States } \\
\hline Year & $\begin{array}{c}\text { Mean } \\
\text { Farm Size }\end{array}$ & $\begin{array}{c}\text { Percent of } \\
\text { Farms }<500 \\
\text { acres }\end{array}$ & $\begin{array}{l}\text { Number of } \\
\text { Farms }\end{array}$ & Year & $\begin{array}{c}\text { Mean } \\
\text { Farm Size }\end{array}$ & $\begin{array}{c}\text { Percent of } \\
\text { Farms }<500 \\
\text { acres }\end{array}$ & $\begin{array}{l}\text { Number of } \\
\text { Farms }\end{array}$ \\
\hline 1880 & 186 & 99 & 44,278 & 1950 & 1,055 & 53 & 160,824 \\
\hline 1890 & 226 & 96 & 102,353 & 1954 & 1,145 & 50 & 151,654 \\
\hline 1900 & 431 & 84 & 107,483 & 1959 & 1,303 & 45 & 134,073 \\
\hline 1910 & 398 & 82 & 201,227 & 1964 & 1,477 & 42 & 120,859 \\
\hline 1920 & 557 & 71 & 223,782 & 1969 & 1,500 & 42 & 116,844 \\
\hline 1925 & 541 & 70 & 217,589 & 1974 & 1,596 & 41 & 109,299 \\
\hline 1930 & 636 & 64 & 220,002 & 1978 & 1,630 & 40 & 105,814 \\
\hline 1935 & 642 & 65 & 227,810 & 1982 & 1,665 & 41 & 101,262 \\
\hline 1940 & 779 & 60 & 191,097 & 1987 & 1,648 & 43 & 103,705 \\
\hline 1945 & 972 & 53 & 170,901 & & & & \\
\hline
\end{tabular}

* data to be added. Source: U.S. Agricultural Census. Great Plains states include eastern Montana and Colorado counties, western counties of the Dakotas, Nebraska and Kansas. Midwestern states include eastern counties of the Dakotas, Nebraska, Kansas, as well as the states of Wisconsin, Minnesota, Iowa, and Illinois. 
Table 2

Congressional Voting on the Enlarged Homestead Act

\begin{tabular}{|l|c|c|}
\hline Independent Variables: & $\begin{array}{l}\text { Dependent Variable: } \\
\text { Yes Votes (of Total State } \\
\text { Yes, No, and Abstentions) }\end{array}$ & $\begin{array}{l}\text { Dependent Variable: } \\
\text { Abstentions (of Total State } \\
\text { Yes, No, Abstentions) }\end{array}$ \\
\hline Constant & $\begin{array}{c}-0.66^{*} \\
(0.16)\end{array}$ & $\begin{array}{c}-0.28 \mathrm{E}-01 \\
(0.15)\end{array}$ \\
\hline \%Change in Population, & $\begin{array}{c}1.64^{*} \\
(0.46)\end{array}$ & $\begin{array}{c}-0.64^{* *} \\
(0.42)\end{array}$ \\
$1900-1910$ & $0.30 \mathrm{E}-08^{*}$ & $-0.36 \mathrm{E}-08^{*}$ \\
Value of Corn & $(.14 \mathrm{E}-08)$ & $(0.14 \mathrm{E}-08)$ \\
Production, 1910 & $-0.32 \mathrm{E}-06^{*}$ & $0.24 \mathrm{E}-06^{*}$ \\
\hline Value of Manufacturing, & $(0.99 \mathrm{E}-07)$ & $(0.93 \mathrm{E}-07)$ \\
1910 & $0.86 \mathrm{E}-01$ & $0.53 \mathrm{E}-01$ \\
$(0.14)$ & $(0.14)$ \\
\hline Republican Party & 382 & 382 \\
\hline N & &
\end{tabular}

Standard Errors in parenthesis

* Significant at $95 \%$ or better

**Significant at $85 \%$ 
Table 3

Drought Survival and Farm Size Cascade and Fergus Counties, Montana

\begin{tabular}{|l|c|c|}
\hline Fergus County & $\begin{array}{c}\text { Number of } \\
\text { Farms }\end{array}$ & $\begin{array}{c}\text { Average 1916 } \\
\text { Farm Size } \\
\text { (acres) }\end{array}$ \\
\hline Total & 3,960 & 315 \\
\hline $\begin{array}{l}\text { Survivors } \\
\text { through 1922 }\end{array}$ & $1,099(28 \%)$ & 383 \\
\hline Non-survivors & $2,861(72 \%)$ & 289 \\
\hline Cascade County & & 328 \\
\hline Total & 2,193 & 373 \\
\hline $\begin{array}{l}\text { Survivors } \\
\text { through 1923 }\end{array}$ & $734(33 \%)$ & 306 \\
\hline Non-survivors & $1,459(67 \%)$ & 424 \\
\hline $\begin{array}{l}\text { Survivors } \\
\text { through 1929 }\end{array}$ & $313(14 \%)$ & \\
\hline
\end{tabular}


Table 4

\begin{tabular}{|l|c|}
\hline $\begin{array}{l}\text { Dependent Variable: } \\
\text { Survival }(\mathbf{0 , 1})\end{array}$ & Coefficient \\
\hline $\begin{array}{l}\text { Explanatory } \\
\text { Variables }\end{array}$ & -1.204 \\
\hline $\begin{array}{l}\text { Community Dummies: } \\
\text { Joliet* }\end{array}$ & $-(2.89)^{* *}$ \\
\hline Roberts & -0.964 \\
& $-(2.06)^{* *}$ \\
\hline Edgar & -0.107 \\
& $-(0.20)$ \\
\hline Silisia & -0.577 \\
& $-(1.23)$ \\
\hline Age & 0.0208 \\
& $(2.53)^{* *}$ \\
\hline Total Crop Acres & 0.00306 \\
& $(1.78)^{* * *}$ \\
\hline Pasture Acres & -0.00223 \\
& $-(1.81)^{* * *}$ \\
\hline Value of Livestock & 0.00028 \\
& $(1.74)^{* * *}$ \\
\hline Value of Wheat Sales & 0.00042 \\
& $(1.57)$ \\
\hline Farm Value per Acre & -0.00949 \\
& $-(2.02)^{* *}$ \\
\hline
\end{tabular}

*Boyd is the baseline Community

** Significant at $5 \%$ level

***Significant at $10 \%$ level 
Table 5

Farm Size Adjustment on the Great Plains, 1920-1982

Montana and Colorado

\begin{tabular}{|l|c|c|}
\hline \multicolumn{1}{|c|}{$\mathbf{1 9 2 0}$} & & Colorado \\
\hline Number of Farms & Montana & 15,294 \\
\hline Less than 100 acres & 4,350 & 33,750 \\
\hline $\mathbf{1 0 0 - 4 9 9}$ acres & 35,723 & 7,482 \\
\hline $\mathbf{5 0 0 - 9 9 9}$ acres & 11,982 & 3,408 \\
\hline Over 1,000 acres & 5,622 & 59,934 \\
\hline Total & 57,677 & 408 acres \\
\hline Mean Farm Size & 608 acres & 1,119 \\
\hline St. Deviation & 1,402 & 2.74 \\
\hline C.V. & 2.30 & \\
\hline & & \\
\hline Number of Farms & & 9,252 \\
\hline Less than 100 acres & 5,593 & 7,761 \\
\hline 100-499 acres & 4,808 & 3,337 \\
\hline 500-999 acres & 2,640 & 6,761 \\
\hline Over 1,000 acres & 10,529 & 27,111 \\
\hline Total & 23,570 & 1,237 acres \\
\hline Mean Farm Size & 2,568 acres & 2,071 \\
\hline St. Deviation & 2,359 & 1.67 \\
\hline C.V. & .92 & \\
\hline
\end{tabular}

Source: U.S. Census 
Figure 1

The Great Plains

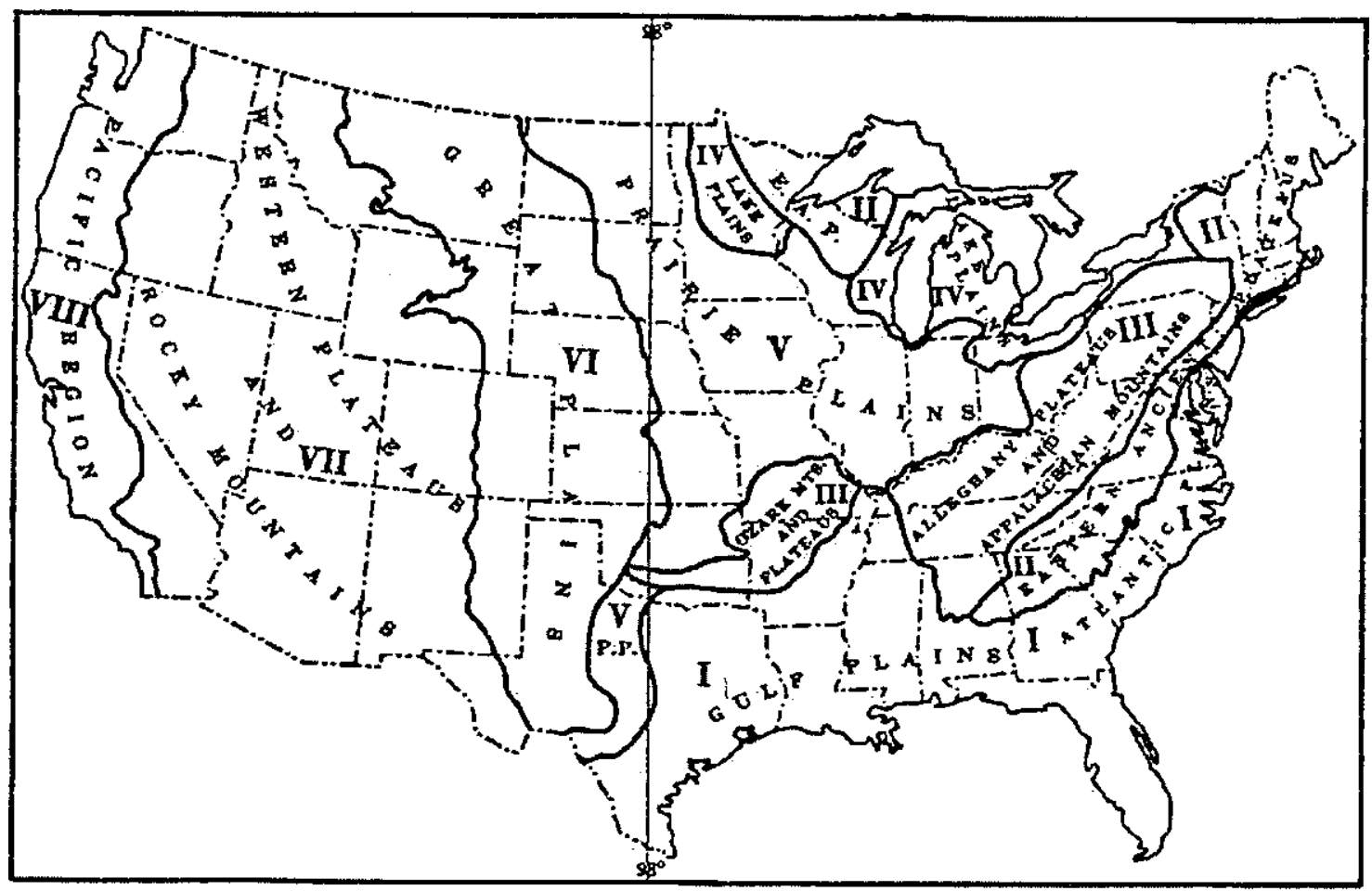


Figure 2

Annual Precipitation in the Great Plains States of Kansas, Colorado, and Montana 1895-1985
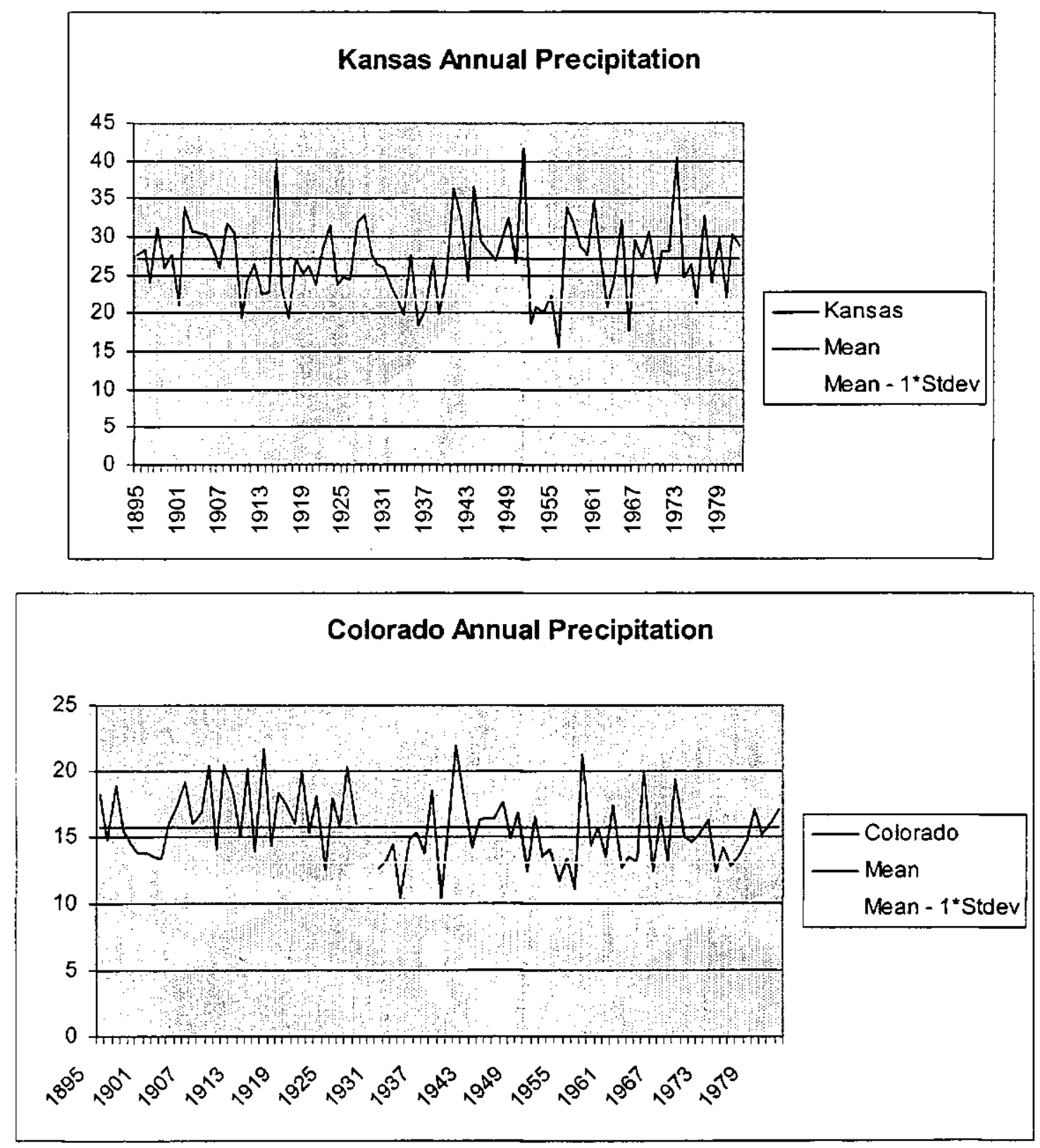


\section{Montana Annual Precipitation}

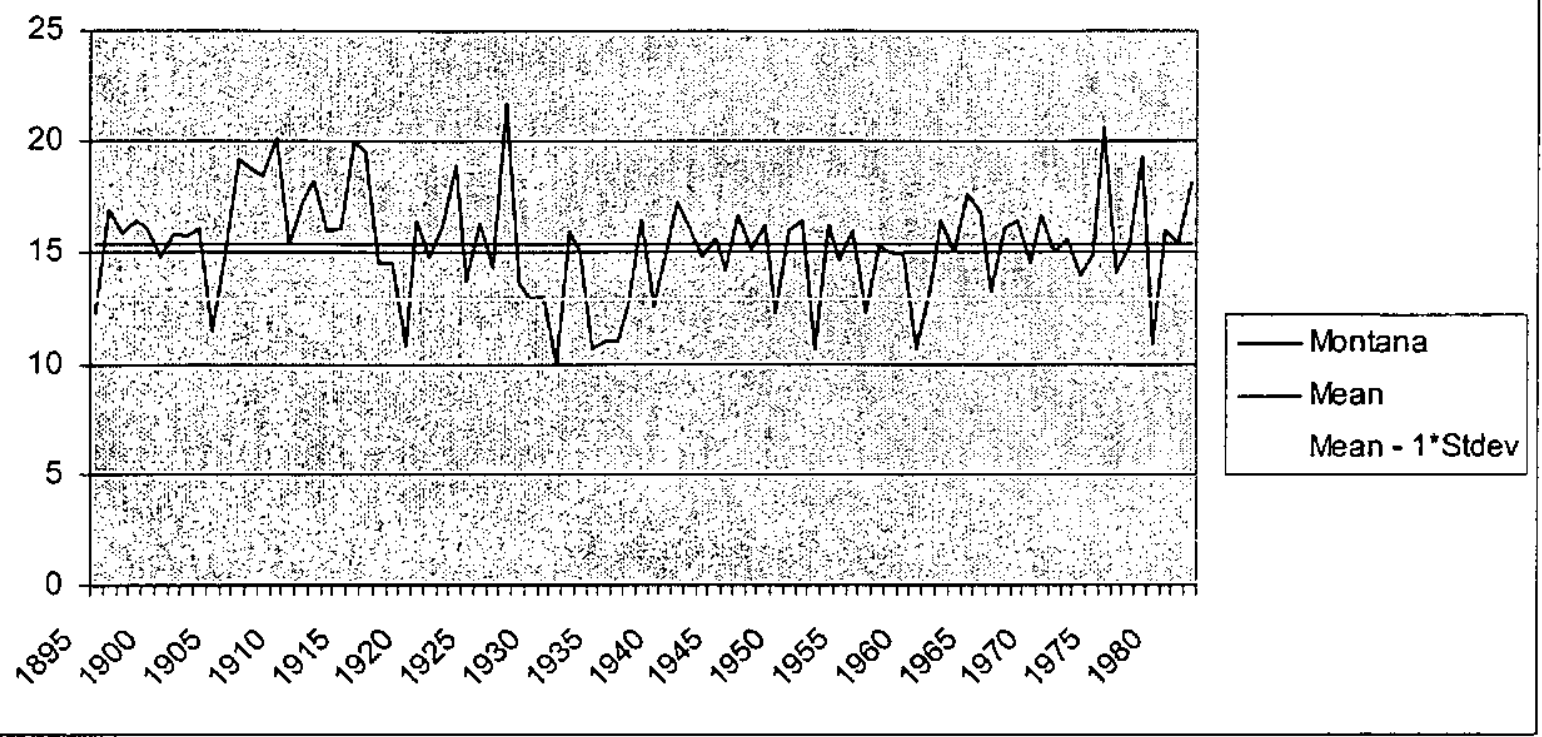


Figure 3

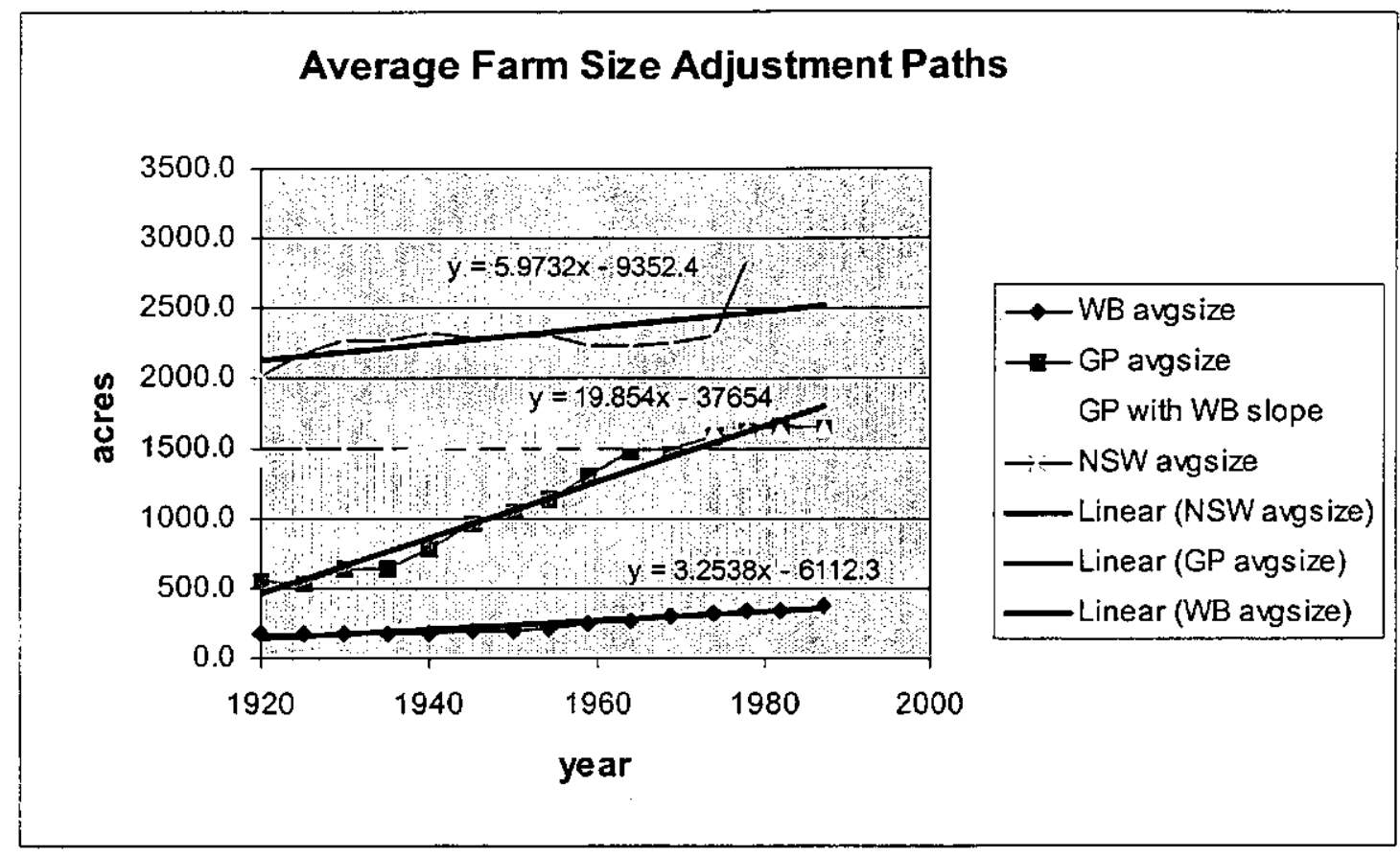




\section{Endnotes}

We are analyzing the relationships between small farms and their cultivation practices and wind erosion. We also are examining the effects of federal government subsidies on the persistence of small farms on the Great Plains. We are collecting data and this draft represents our preliminary results and arguments. In the 1950s and 1970s there were dust storms in the Great Plains, but not of the magnitude of the 1930s.

${ }^{2}$ Coase $(1960,16)$. See also Demsetz $(1967,349)$ for elaboration.

Even though there are fewer small farms today and current farms are larger than in the past, they remain an important political constituency. See Knoeber (1997).

${ }^{4}$ Quoted in Hibbard, (1924, reissued 1965, 143). An example of the congressional debate over the need to reserve federal land for small farmers ("free homes for homeless people") is in Congressional Globe. 37 Congress, $2^{\text {nd }}$ Session, Wednesday May 7, 1862 (page 1915).

'Later, U S D A and Extension Service personnel concluded that the failure to adopt Powell's recommendation was a critical policy error. See for example, the Report of the Great Plains Committee $(1936,1,3,7,40,42)$. Kimmel $(1940,266)$ among others stated that farm reorganization was necessary in order to put into place "agriculture that should have been established in the first place. Had Major Powell's recommendation become a part of the national land policy in the 1870 's many of the problems that now exist never would have occurred."

${ }^{6}$ For discussion of the reaction to Powell's report, see Stegner (1953, 219-42). See Peffer (1951, $8-62,135-68)$ regarding the political controversy over homestead farm size, the claims of ranchers, and efforts to adjust the federal land laws.

The only support came from representatives of eastern states. See Smith (1950, reissued 1970, 199).

${ }^{8}$ Libecap and Hansen (2001) examine the weather information problem facing migrants to the Great Plains. Renne (1936a, 33) also describes the weather information problem confronting settlers. Thomthwaite (1936,202-7), discusses the early lack of information about the region's climate and type of farming that could adapt to it. See also, Kraenzel (1955, 12-23).

Annual Reports of the Commissioner of the General Land Office for the Fiscal Years, 18801925. The calculations are for state totals.

10 The residency requirement for the 1909 law was reduced to three years in 1912 and cultivation was reduced to 160 acres. Other land law changes were the 1873 Timber Culture Act that granted an additional 160 acres if cultivation of trees occurred on 1/4 of the lot; the 1877 Desert Land Act which granted up to 640 acres if part of the farm were irrigated (but in a dry region, this had limited potential); the 1878 Timber and Stone Act which granted 40-160 acres 
for accessing timber or stone for agricultural purposes, and the 1916 Stock Raising Homestead, which granted 640 acres for raising cattle in selected states.

" 35 Stat. 693. The law was passed February 19,1909 in the $60^{\text {th }}$ Congress, $2^{\text {nd }}$ Session. This was one of the few land laws where there are recorded votes for analysis. Data are from the $13^{\text {th }}$ Census of the United States, 1910.

${ }_{12}$ See for example statements given by Senator Gallinger of New Hampshire, Congressional Record. $60^{\text {th }}$ Congress, Second Session, 4214. The objectives to promote actual settlement of small farmers and avoid large accumulations of privately held land are repeated throughout the public lands literature. See Peffer (1951, 134-169) and Hibbard (1924, 386-410).

${ }^{13}$ Congressional Record. $60^{\text {th }}$ Congress, Second Session, 6098, House of Representatives. There were 387 voting, answering "present" or abstaining: 141 yeas, 74 nays, 160 abstentions, and 12 "present." We considered the 12 who answered "present" as abstaining, giving 172 abstentions. We dropped the 5 Oklahoma observations in the analysis because of a lack of data for the independent variables. We estimated the equations using both Probit and OLS, and report the Probit results. They are virtually the same.

${ }^{14}$ Peffer $(1951,33-58)$.

${ }^{15}$ The South had historically opposed homesteading and the Republican party had historically favored it.

${ }^{16}$ Correlation coefficients among some of the independent variables are . -.40 for com state and population change and -.41 for value of manufacturing by state.

17. Early establishments were ranches and often large. Most of the land was held without formal title. Homestead entry intruded on ranches. See Libecap (1981). The data are from County Directories. County Directories were assembled and published privately by R.L. Polk and W.T.Ridgley and are available for many U.S. counties at the Library of Congress. They are not annuals and the data often vary.

18 For example, the classic discussion of the Great Plains is by Webb $(1931,408)$ and he argues that homesteads were too small: "160 acres of land in the humid region was equivalent in productiveness to 2560 acres in the arid region. Other studies that concluded that 160 -acre homesteads were too small includes Stephens (1937), Starch, (1936, 14-19),

19 Huffman and Paschal (1942) argue that "A misguided land settlement policy of the federal government resulted in the settlement of a large part of the Northern Great Plains in relatively small tracts."

20 Calculated from U.S. Department of Commerce, Historical Statistics. 1975, 510, 519 for nominal wheat and livestock prices and 210-11 for the CPI index used as the deflator. 
${ }^{21}$ See Carl F. Kraenzel, (1942, 583-6), "On the whole, farms are too small in the Great Plains region. This is the result of homesteading practices." He called for diversification. Stephens $(1937,751)$, and Bennett and Fowler $(1936,4)$.

22 Eckert and Maughan (1939, 23-4), Kimmel (1940, 265-6). See Alston (1983) for analysis of farm foreclosures during the interwar period. Great Plains states were particularly hard hit.

${ }^{23}$ The survivors and non-survivors are identified by matching the full name of individuals in the directory, including the middle name or middle initial. For Fergus County, the following probit equation was estimated:

Survival 1916 to 1922 (yes/no) $=$ constant $+\beta_{1}$ farm size in 1916 , and for Cascade County:

Survival 1916 to 1923 (yes/no) $=$ constant $+\beta_{1}$ farm size in 1916

Survival 1916 to 1929 (yes/no) $=$ constant $+\beta_{1}$ farm size in 1916 (these farms survived into 1923 , then into 1929)

\begin{tabular}{|l|l|l|}
\hline Dependent Variable: Survival (0/1) & $\begin{array}{l}\text { Coefficient (Std. } \\
\text { Error) }\end{array}$ & $\begin{array}{l}\text { Marginal Effects (Std. } \\
\text { Error) }\end{array}$ \\
\hline Fergus Probit Results(1916 to 1922) & & \\
\hline Constant & $-0.71(0.029)$ & $-0.237(0.75 \mathrm{E}-2)$ \\
\hline Size of Farm in 1916 & $0.365 \mathrm{E}-3(0.59 \mathrm{E}-4)$ & $0.122 \mathrm{E}-3(0.19 \mathrm{E}-4)$ \\
\hline Cascade Probit Results (1916 to 1923) & & \\
\hline Constant & $-0.50(0.354)$ & $-0.183(0.011)$ \\
\hline Size of Farm in 1916 & $0.225 \mathrm{E}-3(0.66 \mathrm{E}-4)$ & $0.82 \mathrm{E}-4(0.24 \mathrm{E}-4)$ \\
\hline Cascade Probit Results (1916 to 1929) & & \\
\hline Constant & $-1.07(0.04)$ & $-0.26(0.54 \mathrm{E}-2)$ \\
\hline Size of Farm in 1916 & $0.29 \mathrm{E}-3(0.66 \mathrm{E}-4)$ & $0.72 \mathrm{E}-4(0.16 \mathrm{E}-4)$ \\
\hline
\end{tabular}

For Fergus, the results indicate that for 1,000 -acre increase from the average farm size, the probability of survival increases by 0.12 . This small increase in probability is likely to be due to the problem of not being able to control other factors, such as experience or land quality. The probability of survival at the mean farm size of 315.1 in 1916 acres is 0.28 . The probability of survival at mean plus one standard deviation of farm size (i.e. 708 acres) is 0.33 . For a farm of 1,000 acres, the probability of survival is estimated to be 0.37 , and for 1,425 acre farm the probability of survival increases to 0.57 .

For Cascade, the results indicate that for 1,000-acre increase from the average farm size, the probability of survival from 1916 to 1923 increases by 0.02 . Similarly, for 1,000 acre-increase from the mean, the probability of survival from 1916 to 1929 increases by 0.03 . The probability of survival from 1916 to 1923 at the overall 1916 mean farm size of 328.3 acres is estimated to be 0.33 . There is a $33 \%$ chance that a farm with average acreage would survive into 1923 from 1916, given the 1916 farm size. Survival probability rises to 0.37 at 750.1 acres (mean + one std. deviation). Survival probability to 1929 is much lower at the mean acreage of 328.3 ; the probability of survival into 1929 with mean acreage is 0.17 , and with mean + one std. Deviation is only 0.2 . The survival probability to 1929 rises to 0.22 when farm size is 1,000 acres.

${ }^{24}$ Data used in this analysis are compiled from two sources: Carbon County Directories, 1916 , 1919, 1922, R.L. Polk and W.T.Ridgley, from the Library of Congress and the 1919 
Agricultural Census Manuscript for Carbon County, Montana, US National Archives. Prices received by farmers for wheat, oats and potatoes sold are compiled from the USDA.

${ }^{23}$ We include farmers that were listed in 1922 but not in 1919 for some reason, but had to have been there in 1919 .

${ }^{26}$ A "non survivor" might have failed due to drought, might have sold the farm, or passed it along to heirs. We cannot distinguish among these options, but attempt to control for them in the statistical analysis.

${ }^{27}$ The county directories include the farmer's name, acreage, assessed value, and post office location. Because some names are common ones, to distinguish farmers we relied on post office addresses.

${ }^{28}$ Farmers older than 65 in 1919 might not have "survived" because of health or death, rather than due to the effects of drought. We also use dummy variables to control for fixed effects of location. Location is based on post office addresses given in the county directories. These included Red Lodge, Luther, Laurel, Boyd, Joliet, Edgar, Silisia, and Roberts. Because some communities had all non-survivors, they too were dropped from the analysis, affecting 14 farmers.

29 Age was consistently significant at 5 percent or better in various runs. Other experience variables considered were years as farm owner, years as farm operator, and whether the individual owned the farm (yes/no), but none performed as well. We also considered including sex, but almost all farmers were male.

${ }^{30}$ This variable is pasture for livestock only, deleting pasture for crops as included in the census. The total crop acres variable already includes crop land.

${ }^{31}$ We considered a variety of financial and capital variables constructed from the census and most did not perform well, possibly because they were either not complete or well defined

${ }^{32}$ The value of livestock is for livestock that can be sold. We do not include horse value since horses were capital stock for these farms and used in plowing the cultivated acres.

${ }^{33}$ We experimented with a variety of wheat and crop variables in levels and shares. The value of winter and spring wheat sales was by far the most powerful variable.

${ }^{34}$ The descriptive statistics are:

\begin{tabular}{|c|c|c|}
\hline Variable & Mean & Std. Dev. \\
\hline Joliet* & \begin{tabular}{|l|}
0.44 \\
\end{tabular} & $\begin{array}{r}0.50 \\
\end{array}$ \\
\hline Roberts* & 0.17 & 0.38 \\
\hline Edgar* & 0.10 & 0.30 \\
\hline Silisia* & 0.15 & 0.36 \\
\hline Age & 44.98 & 11.02 \\
\hline
\end{tabular}




\begin{tabular}{|c|c|c|}
\hline Total Crop Acres & 144.58 & 96.56 \\
\hline Pasture Acres & 146.39 & 136.31 \\
\hline Value of Livestock & 1426.49 & 4231.39 \\
\hline Value of Wheat Sales & 238.27 & 612.95 \\
\hline Farm Value per Acre & 49.28 & 42.32 \\
\hline
\end{tabular}

${ }^{33}$ The historical literature on the Dust Bowl is large, but not very analytical. Gutmann and Confer (1999) is an exception. Standard references include Worster (1979), Hurt (1981), and Bonnifield (1979). The US D A and agricultural economics literature provide more quantitative data. For an assessment of its impact, see Worster $(1979,5,12,13,29,22-24)$ and Bennett (1939, 55-87). Bennett was head of the Soil Conservation Service.

${ }^{36}$ Bennett (1939, 119-21).

${ }^{37}$ Thomthwaite $(1936,238-40)$. In 1936 Bennett and Fowler $(1936,8)$ claimed that because of the dust storms of 1934 and 35, 80 percent of the Great Plains were in some state of erosion, with "as much as 15 percent may already have been seriously and permanently injured."

38 1938 Yearbook of Agriculture. "Soils and Men," page 71.

${ }^{39}$ Bennett (1939, 118).

${ }^{40}$ Stephens (1937), Starch (1939), Great Plains Committee, (1936, 27-32) reported that the climate of the region was uncertain with light rainfall and the windiest conditions in the US. Clements $(1938,199)$ argued that cultivation was the key causal factor in the Dust Bowl. Gutmann and Cunfer (1999) point out that drought conditions associated with the Dust Bowl have long characterized the Great Plains. Whether or not wind erosion as severe as that of the 1930s occurred earlier is unknown. If our hypothesis is correct, it is unlikely. In their study, Gutmann and Cunfer statistically examine the determinants of dust storms between 1961 and 1988 for 39 weather stations in the Great Plains where relatively complete data exist. Because data are not available for the Dust Bowl years, they use the estimated coefficients to predict the incidence of dust storms for Great Plains counties between 1930 and 1990. Their results under predict the number of dust storms for 1934-35, the test period. They argue that unusually high temperatures during that time were major contributing factors.

${ }^{41}$ The 1937 Yearbook of Agriculture, pages 33-37 commented on the severe drought that prevailed in 1936 and for the previous 3 years. Gutmann and Cunfer (1999) argue that high temperatures in the 1930 s played a critical role. They agree that cultivation practices compounded conditions. They do not find a clear relationship between wheat acreage and the incidence of wind erosion. But they do not examine cultivation practices on small farms. 
${ }_{42}$ Worster $(1979,85)$. In examining the causes of the Dust Bowl, Bennett, Kenney, and Chapline (1938, 68-76) criticized past homestead policies and pointed to "repeated attempts at too intensive use of the soil have resulted in serious problems of depletion, in destruction of physical resources...."Kimmel $(1940,264)$ linked the Dust Bowl to the dense settlement of the plains by homesteaders who put the land into cultivation, displacing grass land. Bennett and Fowler (1936, 4-10) emphasized the use of farming practices that were brought from the East, but inappropriate for a semi-arid region. They particularly pointed to excessive plowing. They also pointed to overgrazing as contributing to the removal of land cover.- How important this was in a region dominantly in grain is unclear. Ranchers did have very uncertain property rights to range land because they could not obtain title to the land that they used under the land laws. For discussion of this issue, see Libecap (1981).

${ }_{43} 1938$ Yearbook of Agriculture, "Soils and Men," pages 686-688. Summer fallow was the greatest source of moisture conservation. Hewes $(1979,167)$ discusses the costs of summer fallow, but does not make specific reference to whether small farms used it or not. Kraenzel $(1955,311)$ also discusses the problems of small farmers with a maximum of 320 acres. He noted that summer fallow could not make progress until farms were large enough. See also, Clawson, Saunderson and Johnson (1940, 36-41). Renne, (1936a, 33) argued that ranches in the Great Plains had to be 6 to 8,000 acres to sustain a minimum sized herd of 200 animals and a farm 800 acres to allow for a minimum of 400 acres in crop and 400 acres in fallow each year.

${ }^{44}$ For the transitional states that were bisected by the $100^{\text {th }}$ meridian we used county data following the Great Plains division described in Hargreaves (1957) for Montana and the Dakotas and Fite (1966) for Kansas. We connected these divisions through Nebraska. We also used just the eastern, non-mountain counties of Colorado.

${ }^{45}$ Through the 1920s and 30s, US D A and extension service officials were extremely critical of past land policy and the small homesteads it created. During the 1930s, there were repeated calls for Federal Government policies to promote farm consolidation and the resettlement of "stranded farm families For example, see Johnson $(1937,153)$ and Great Plains Committee $(1936,79)$.

${ }^{46}$ Great Plains Committee $(1936,1)$ argued that many of the region's problems were associated with past land laws that encouraged homestead settlement. The committee noted that even so, the farmers "were in no mood to abandon their land."

${ }^{47}$ Renne (1936b, 49), Hargreaves (1976, 565-68). The various agencies involved in farm support and population resettlement included Federal Emergency Relief Organization (1933-35), Resettlement Administration (1935-7), Farm Security Administration (1937-8), and Soil Conservation Service (1938).

${ }_{48}$ Worster (1979, 42-6). The Farm Security Administration took over for the unpopular Resettlement Administration. But the Farm Security Administration, with its emphasis on small farmers, also faced political reaction from organizations representing larger farmers, such as the Farm Bureau Federation. 
Hurt $(1985,249-58)$.

He called for the slow removal of 900,000 people or 210,000 families. He presented numbers of "surplus families" by state: North Dakota 7,360, Montana 12,610, Colorado 2,580, Texas 12,200, Oklahoma 2,930, Kansas, 6,100, Nebraska 4,930, and South Dakota 4,640. Worster $(1979,48,59-60)$. Great Plains Committee $(1936,72)$ stated that 165,000 individuals had moved from the Great Plains by 1936.

${ }^{51}$ Worster (1979, 37-40, 124). The Secretary of Agriculture, Annual Report. $(1943,176)$ noted that Farm Security Administration Loan recipients are usually small farmers.

in Bennett $(1939,90)$ noted that farms in the Great Plains required more government loans, credit, and other forms of relief. Thornthwaite $(1936,246)$ stated that "It is evident that many of the farmers have been able to remain on their land only through a succession of loans." Johnson (1937, 162) stated that failing farms have appealed to Congress for seed and feed loans and other relief. In some counties the total of feed and seed loans and relief aid poured into some counties since 1929 exceeded the purchase value of the dryfarming land. The Great Plains Committee (1936, 5, 55-8) estimated that between April 1933 and June 1936 the Federal Government provided aid that in some counties equaled S200 per person and noted the excessive dependency of farms in the region on various forms of federal relief.

${ }^{33}$ Saunderson, Haight, Peterson, and Willard $(1937,18)$ were critical of the effects of government relief which delayed adjustment toward more viable farm units.

${ }^{54}$ This action maintained the strength of their political coalition (Knoeber, 1997). 